\title{
Cost-Effectiveness Analysis of Antihypertensive Drug Use in Hypertension- Diabetes Mellitus and Hypertension-Heart Failure Inpatients at a Government Hospital
} in Yogyakarta, Indonesia

\author{
$1^{\text {st }}$ Faridah Baroroh \\ Faculty of Pharmacy \\ Ahmad Dahlan University \\ Yogyakarta, Indonesia \\ faridah@pharm.uad.ac.id
}

\author{
$2^{\text {nd }}$ Andriana Sari \\ Faculty of Pharmacy \\ Ahmad Dahlan University \\ Yogyakarta, Indonesia \\ andrisarii13@gmail.com
}

\author{
$3^{\text {rd }}$ Khansa Zakiyatul Laili \\ Faculty of Pharmacy \\ Ahmad Dahlan University \\ Yogyakarta, Indonesia \\ khansazakii145@gmail.com
}

\author{
$4^{\text {th }}$ Dina Putri Permatasari \\ Faculty of Pharmacy \\ Ahmad Dahlan University \\ Yogyakarta, Indonesia \\ dinaapp999@gmail.com
}

Corresponding author: faridah@pharm.uad.ac.id

\begin{abstract}
Hypertension and diabetes mellitus are the leading risk factors for cardiovascular diseases, which are increasing rapidly throughout the world. Hypertension is a non-communicable disease that remains a health problem in Indonesia, with a prevalence of up to $34.11 \%$ in 2018 . This research was intended to identify cost- effective antihypertensive medication for inpatients with hypertension-diabetes mellitus and hypertensionheart failure. The research method used a retrospective cohort design and measured blood pressure (BP) 72 hours after treatment as the outcome of the observation. Based on a payer perspective, the medical expense was calculated from direct medical costs written in billing invoices. The research subjects were inpatients with hypertension-diabetes mellitus and hypertension-heart failure at a government hospital in Yogyakarta, Indonesia. In the cost- effectiveness analysis, Incremental Cost-Effectiveness Ratio (ICER) was calculated by dividing the difference in cost by the difference in the outcome of hypertension treatment.In the antihypertensive medication of hypertension-diabetes mellitus inpatients, angiotensin-receptor blockers/ calciumchannel blockers (ACB-CCB) were found to be more cost-effective than $\mathrm{CCB}$ with incremental costs of IDR 191,405/488,864 for every $\mathrm{mmHg}$ decrease of systolic/diastolic BP. Meanwhile, in the antihypertensive treatment of hypertension-heart failure inpatients, the combination of angiotensin-converting- enzyme inhibitors (ACEI) and diuretics was more cost-effective than ACEI-CCB (ICERs= IDR 8,303,483/-39,856,718 per mmHg) and ARB (ICERs= IDR 3,627,694/-2,380,075 per mmHg).In conclusion, ARB-CCB is a cost-effective medication for hypertension-diabetes mellitus inpatients, while ACEI-Diuretics offers a cost-effective hypertensive treatment for hypertension-heart failure inpatients.
\end{abstract}

Keywords: Cost-effectiveness analysis, antihypertensive, inpatient, hypertension-diabetes mellitus, hypertensionheart failure.

\section{INTRODUCTION}

Hypertension and diabetes mellitus are the leading risk factors for cardiovascular diseases, which are increasing rapidly throughout the world [1]. Hypertension is a type of non- communicable disease that remains a health problem in Indonesia. Also, it has a $34.11 \%$ prevalence among populations aged $\geq 18$ years in the country [2].

Hypertensive patients commonly own higher risks of developing diabetes mellitus that can trigger cardiovascular diseases [3]. Diabetes mellitus is the most frequent complication $(60.60 \%)$ [4]. [5]. The prevalence of hypertension with diabetes mellitus as comorbidity is $10.26 \% ; 26.4 \%$ of which has a family history of diabetes $(26.4 \%$ ), and $20.4 \%$ has a family history of hypertension [6]. Diabetes mellitus and hypertension often co-occur [7]. Throughout the world, both diseases persistently increase in prevalence and cause severe complications, including cardiovascular diseases and chronic kidney failure, which in the long term, raise the risk of death by $50 \%$ in diabetic patients with hypertension and around 20\% in hypertensive patients with diabetes mellitus. People with hypertension or diabetes mellitus have 1.5 to 2.0 times higher risk of suffering from both conditions [8].

The etiology of heart failure is hypertensive heart disease $(47.7 \%)$, and to treat this, discharged patients receive loop diuretics $(97.9 \%)$, ACEI (70.9\%), betablockers $(36.9 \%)$, and aldosterone antagonist $(50.6 \%)$ [9]. Thiazide diuretics are reported to exhibit better effectiveness than ACEI in cases of acute myocardial infarction $\quad(\mathrm{HR}=0.84 ; \quad 95 \% \quad \mathrm{CI} \quad 0.75-0.95)$, 
hospitalization due to heart failure $(0.83 ; 0.74-0.95)$, and stroke $(0.83 ; 0.74-0.95)$ [10]. Hypertension treatment has been verified to prevent and reduce many clinical presentations related to heart failure, such as an increase in left ventricular hypertrophy $(\mathrm{LVH})$ and left ventricular mass [11].

Incremental Cost-Effectiveness Ratio (ICER) is the difference in treatment costs divided by the difference in the medication effects. It is a vital component in cost-effectiveness analysis [12].This research was intended to identify cost-effective antihypertensive medication for inpatients with hypertension- diabetes mellitus and hypertension-heart failure.

\section{METHODS}

This study has received ethical approval, No. $\mathrm{KE} / \mathrm{FK} / 0200 / \mathrm{EC} / 2019$, from the Medical and Health Research Ethics Committee (MHREC) of the Faculty of Medicine, Universitas Gadjah Mada. With a retrospective cohort design, it measured drug effectiveness from the treatment outcome, viz. decreased systolic and diastolic BP $(\mathrm{mmHg}) 72$ hours after the administration of antihypertensives. Based on a payer perspective, the medical expense was calculated from direct medical costs written in billing invoices. The research subjects were inpatients with hypertension-diabetes mellitus and hypertension-heart failure at a government hospital in Yogyakarta, Indonesia.

These subjects were selected using a set of inclusion criteria, namely inpatients diagnosed mainly with hypertension (ICD10: I10), taking antihypertensives, registered as BPJS (health insurance) participants, and in their first hospital admissions. Meanwhile, inpatients were excluded when they had taken different medications during the observation phase and their medical records and outcome measurements were incomplete.

In the cost-effectiveness analysis, Incremental CostEffectiveness Ratio (ICER) was calculated by dividing the difference in cost by the difference in the outcome of hypertension treatment in two groups of inpatients. This research also employed a difference test, namely, t-test, to determine the absence or presence of difference in mean systolic-diastolic BP among the groups (based on sex, age, type of therapy, and length of hospital stay). Bivariate analysis using a chi-square test was also used to ascertain the factors contributing to changes in BP after undergoing the treatment (i.e., sex, age, type of therapy, and length of hospital stay).

\section{RESULT}

\section{A. Hypertension-diabetes mellitus}

A total of 35 patients met the inclusion and exclusion criteria, 24 of which took ARB-CCB combination, and the remaining 11 underwent monotherapy with $\mathrm{CCB}$. As calculated using ICER, the cost-effectiveness of hypertension therapy in hypertension- diabetes mellitus inpatients is presented in Table 1.

Table 1. The ICERs of hypertension-diabetes mellitus treatment

\begin{tabular}{cccc}
\hline Therapy & $\begin{array}{c}\text { Mean Cost } \\
\text { (IDR) }\end{array}$ & $\begin{array}{c}\text { Therapeutic } \\
\text { Effectiveness } \\
\text { (mmHg) }\end{array}$ & $\begin{array}{c}\text { ICER } \\
\text { (IDR/m } \\
\text { mHg) }\end{array}$ \\
\hline ARB-CCB & $3,873,781.70$ & $26.54 / 6.46$ & $\begin{array}{l}191,405 / 48 \\
8,864\end{array}$ \\
\hline CCB & $2,760,874.22$ & $20.73 / 4.18$ & \\
\hline
\end{tabular}

Seventy-two hours after the treatment, the BP reductions (outcomes) in hypertension-diabetes mellitus inpatients were averagely $24.71 \mathrm{mmHg}$ systolic BP and $5.74 \mathrm{mmHg}$ diastolic BP. The length of stay (LOS) was averagely seven days; hence, in the ttest and analysis of contributing factors, it was categorized into two, namely, less than and equal to/more than seven days. The $\mathrm{t}-$ test results, aiming to determine the changes in systolic and diastolic BP, are summarized in Table 2.

Table 2. The difference t-test results of changes in the systolic and diastolic blood pressure of hypertension-diabetes mellituspatients

\begin{tabular}{|c|c|c|c|}
\hline \multirow{2}{*}{\multicolumn{2}{|c|}{ Patient characteristics }} & \multicolumn{2}{|c|}{$p$-values } \\
\hline & & Systolic & Diastolic \\
\hline \multirow[t]{2}{*}{ Sex } & Male & \multirow{2}{*}{0.800} & \multirow{2}{*}{0.893} \\
\hline & Female & & \\
\hline \multirow[t]{2}{*}{ Age } & $<60$ у.о. & \multirow{2}{*}{0.430} & \multirow{2}{*}{0.488} \\
\hline & $>60$ y.o. & & \\
\hline \multirow[t]{2}{*}{ Type of Therapy } & ARB-CCB & \multirow{2}{*}{0.172} & \multirow{2}{*}{0.541} \\
\hline & $\mathrm{CCB}$ & & \\
\hline \multirow[t]{2}{*}{ Length of Stay } & $<7$ days & \multirow{2}{*}{0.050} & \multirow{2}{*}{0.546} \\
\hline & $\geq 7$ days & & \\
\hline
\end{tabular}

The analysis results of factors that were predicted to influence changes in systolic and diastolic BP (<average and $\geq$ average) in hypertension-diabetes mellitus inpatients are presented in Table 3 
Table 3. Factors predicted to influence blood pressure in hypertension- diabetes mellitus patients

\begin{tabular}{|c|c|c|c|c|c|}
\hline \multirow[b]{2}{*}{ Factors } & & \multirow[b]{2}{*}{$\begin{array}{c}p \text { - } \\
\text { values }\end{array}$} & \multirow{2}{*}{$\begin{array}{c}\text { Systolic } \\
\text { Relative } \\
\text { Risk } \\
\text { (RR) } 95 \% \\
\text { CI }\end{array}$} & \multicolumn{2}{|c|}{ Diastolic } \\
\hline & & & & $\begin{array}{c}p \text { - } \\
\text { values }\end{array}$ & $\begin{array}{c}\text { Relative } \\
\text { Risk } \\
\text { (RR) } \\
\text { 95\% CI }\end{array}$ \\
\hline Sex & $\begin{array}{l}\text { Male } \\
\text { Female }\end{array}$ & 0.890 & $\begin{array}{c}0.955 \\
(0.491- \\
1.554)\end{array}$ & 0.129 & $\begin{array}{c}0.577 \\
(0.265- \\
1.257)\end{array}$ \\
\hline Age & $\begin{array}{l}<60 \text { y.o. } \\
>60 \text { y.o. }\end{array}$ & 0.521 & $\begin{array}{c}0.800 \\
(0.418- \\
1.533)\end{array}$ & 0.032 & $\begin{array}{c}0.500 \\
(0.282- \\
0.885)\end{array}$ \\
\hline $\begin{array}{l}\text { Type of } \\
\text { Therapy }\end{array}$ & $\begin{array}{l}\text { ARB- } \\
\text { CCB } \\
\text { CCB }\end{array}$ & 0.109 & $\begin{array}{c}2.000 \\
(0.736- \\
5.433)\end{array}$ & 0.915 & $\begin{array}{c}1.040 \\
(0.504- \\
2.148)\end{array}$ \\
\hline $\begin{array}{l}\text { Length } \\
\text { of Stay }\end{array}$ & $<7$ days & 0.238 & $\begin{array}{c}1.484 \\
(0.754- \\
2.921)\end{array}$ & 0.862 & $\begin{array}{c}0.944 \\
(0.496- \\
1.798)\end{array}$ \\
\hline
\end{tabular}

\section{A. Hypertension-heart failure}

A total of 32 patients met the inclusion and exclusion criteria, 13 of which took ACEI-Diuretics, 13 used ACEI-CCB, and 6 received ARB. As calculated using ICER, the cost-effectiveness of hypertension therapy in hypertension-heart failure inpatients is reported in Table 4

Table 4. The ICERs of hypertension-heart failure treatment

\begin{tabular}{lccc}
\hline \multicolumn{1}{c}{ Therapy } & $\begin{array}{c}\text { Mean } \\
\text { Cost } \\
\text { (IDR) }\end{array}$ & $\begin{array}{c}\text { Therapeutic } \\
\text { Effectiveness } \\
\text { (mmHg) }\end{array}$ & $\begin{array}{c}\text { ICER } \\
\text { (IDR/mmHg) }\end{array}$ \\
\hline $\begin{array}{l}\text { ACEI- } \\
\text { Diuretics }\end{array}$ & $29,044,755.57$ & $29.77 / 8.23$ & $8,303,483 /$ \\
\hline ACEI-CCB & $13,715,248.46$ & $27.92 / 8.62$ & $-39,856,718$ \\
\hline $\begin{array}{l}\text { ACEI- } \\
\text { Diuretics }\end{array}$ & $29,044,755.57$ & $29.77 / 8.23$ & $3,627,694 /$ \\
\hline ARB & $11,743,443.64$ & $25.00 / 15.5$ & $-2,380,075$ \\
\hline ACEI-CCB & $13,715,248.46$ & $27.92 / 8.62$ & $674,565 /$ \\
\hline ARB & $11,743,443.64$ & $25.00 / 15.5$ & $-286,407$ \\
\hline
\end{tabular}

Hypertension-heart failure inpatients experienced a decrease of averagely $22.59 \mathrm{mmHg}$ systolic and 9.72 $\mathrm{mmHg}$ diastolic BP. The length of stay (LOS) was averagely five days; hence, in the t-test and analysis of contributing factors, it was categorized into two, namely, less than and equal to/more than five days. The $\mathrm{t}$ - test results, aiming to determine changes in systolic and diastolic BP, arepresented in Table 5
Table 5. The difference t-test results of changes in the systolic and diastolic blood pressure of hypertensionheart failure patients

\begin{tabular}{|c|c|c|c|}
\hline \multirow{2}{*}{ Factors } & & \multicolumn{2}{|c|}{$p$-values } \\
\hline & & Systolic & Diastolic \\
\hline \multirow[t]{2}{*}{ Sex } & Male & \multirow{2}{*}{0.835} & \multirow{2}{*}{0.649} \\
\hline & Female & & \\
\hline \multirow[t]{2}{*}{ Age } & $<60$ y.o. & \multirow{2}{*}{0.496} & \multirow{2}{*}{0.258} \\
\hline & $>60$ y.o. & & \\
\hline \multirow[t]{2}{*}{ Length of Stay } & $<5$ days & \multirow{2}{*}{0.246} & \multirow{2}{*}{0.300} \\
\hline & $\geq 5$ days & & \\
\hline \multirow[t]{2}{*}{ Type of Therapy } & ACEI-Diuretics & \multirow{2}{*}{0.254} & \multirow{2}{*}{0.198} \\
\hline & ACEI-CCB & & \\
\hline
\end{tabular}

The analysis results of factors predicted to influence changes in the systolic and diastolic BP (<average and $\geq$ average) of hypertension-heart failure inpatients are presented in Table 6

Table 6. Factors predicted to influence blood pressure in hypertension- heart failure patients

\begin{tabular}{|c|c|c|c|c|c|}
\hline \multirow{2}{*}{\multicolumn{2}{|c|}{ Factors }} & \multicolumn{2}{|c|}{ Systolic } & \multicolumn{2}{|c|}{ Diastolic } \\
\hline & & $p$ - & RR $(05 \%$ CD & $p-$ & RR $(05 \% \mathrm{CI}$ \\
\hline \multirow[t]{2}{*}{ Sex } & Male & \multirow[b]{2}{*}{0.863} & 0929 & \multirow[b]{2}{*}{0.102} & \multirow{2}{*}{$\begin{array}{c}1.917 \\
(0.928-3.960)\end{array}$} \\
\hline & $\begin{array}{l}\text { Fema } \\
\text { le }\end{array}$ & & $(0.399-2.166)$ & & \\
\hline \multirow[t]{4}{*}{ Age } & $<60$ & \multirow{4}{*}{0.688} & & \multirow{4}{*}{0.025} & \multirow{4}{*}{$\begin{array}{c}2.852 \\
(0.980-8.303)\end{array}$} \\
\hline & y.o. & & 1.167 & & \\
\hline & $>60$ & & $(0.545-2.497)$ & & \\
\hline & y.o. & & & & \\
\hline \multirow{3}{*}{$\begin{array}{l}\text { Leng } \\
\text { th of } \\
\text { Stay }\end{array}$} & $<5$ & \multirow{3}{*}{0.169} & \multirow{3}{*}{$\begin{array}{c}0.599 \\
(0.289-1.241)\end{array}$} & \multirow{3}{*}{0.821} & \multirow{3}{*}{$\begin{array}{c}0.912 \\
(0.414-2.008)\end{array}$} \\
\hline & days & & & & \\
\hline & $\begin{array}{l}\geq 5 \\
\text { days }\end{array}$ & & & & \\
\hline \multirow{5}{*}{$\begin{array}{l}\text { Type } \\
\text { of } \\
\text { Ther } \\
\text { apy }\end{array}$} & ACEI & \multirow{5}{*}{0.239} & \multirow{5}{*}{$\begin{array}{c}1.600 \\
(0.711-3.600)\end{array}$} & \multirow{5}{*}{0.116} & \multirow{5}{*}{$\begin{array}{c}2.000 \\
(0.796-5.027)\end{array}$} \\
\hline & & & & & \\
\hline & Diure & & & & \\
\hline & tics & & & & \\
\hline & ACEI & & & & \\
\hline & the & & $n$ of only tw & $\mathrm{s} t$ & filled the \\
\hline
\end{tabular}

\section{DISCUSSION}

\section{A. Hypertension-diabetes mellitus}

Based on the ICER presented in Table I, ARB-CCB was more cost-effective than $\mathrm{CCB}$ with incremental costs of IDR 191,405 and 488,864 per $1 \mathrm{mmHg}$ decrease of systolic and diastolic BP, respectively. The ARB-CCB combination costs more expensive than $\mathrm{CCB}$ (monotherapy). However, this high price is comparable to the better effectiveness of ARB-CCB 
relative to $\mathrm{CCB}$. In conclusion, hypertension therapy with ARB-CCB combination is more cost-effective in lowering $\mathrm{BP}$ of inpatients with hypertension-diabetes mellitus. At a standard dose, it results in more significant reductions in systolic and diastolic BP than high-dose monotherapy of CCB [13].

As seen in Table 2, the t-test revealed that the changes in systolic and diastolic BP had no significant differences $(p \geq 0.05)$. Sex (male or female) is reported to have a significant negative correlation with BP levels [14].

Factors predicted to affect changes in systolic BP were the type of therapy $(\mathrm{RR}=2.000 ; 0.736-5.433)$ and length of stay $(\mathrm{RR}=1.484 ; 0.754-2.921)$. Overall, ARBCCB led to better hypertension control than CCB $(\mathrm{RR}=1.17,95 \% \mathrm{CI}: 1.08-1.26)$ [13]. The variables observed (i.e., sex, age, calorie intake from drinks, calorie intake from food, change in body weight, initial $\mathrm{BP}$, and physical exercise) were not predictors of diastolic BP reduction [15].

\section{A. Hypertension-heart failure}

Based on the ICERs in Table 4, ACEI-Diuretics combination was more cost-effective in lowering systolic BP than ACEI- CCB, with an incremental cost of IDR 8,303,483. Angiotensin- converting-enzyme inhibitor (ACEI) and angiotensin II receptor blockers (ARB) are used primarily to treat hypertension and beneficial to improving heart failure and chronic kidney disease [16]. Adding diuretics instead of $\beta$ blockers to the treatment of hypertensive patients with a history of cerebrovascular accident (CVA) and ACEI/ARB and CCB use is deemed more therapeutic [17].

In lowering the diastolic BP, absolute ACEI-CCB was more cost - effective than ACEI-Diuretics, with an ICER of IDR - to prevent stroke and myocardial infarction (MI) among Chinese patients with uncontrolled hypertension [21]. Contrary to systolic BP reduction, ARB was more cost-effective in lowering diastolic BP than ACEI-CCB, with an ICER of IDR 286,407 . ARB is proven to be more cost-effective compared to CCB, ACEI, and $\beta$-blocker [22][23].

As seen in Table $\mathrm{V}$, the t-test revealed that the changes in systolic and diastolic BP had no significant differences ( $p \geq 0.05)$. Sex (male or female) is reported to have a significant negative correlation with BP levels [14]. Although the BP- lowering effects of all antihypertensive drugs tested in the study had no significant differences, discontinuation is a consequence of undesirable side effects. For instance, diuretics can induce frequent urination, which potentially leads to lowered adherence to medication [24].

The factor predicted to modify systolic BP is the type of therapy ( $R R=1.6 ; 0.711-3.600)$. In patients with a previous history of cerebrovascular accident (CVA), ACEI-CCB-Diuretics combination enables them to have a significantly higher event- free survival from acute myocardial infarction (AMI) than ACEI- CCB- $\beta$ blockers $\quad(\mathrm{HR}=1.56 ; \quad 95 \% \quad$ CI $1.051-30.307 ; \mathrm{p}$ $<0.05)$ [17]. Factors predicted to affect changes in systolic BP were age $(\mathrm{RR}=2.852 ; 0.980-8.303)$, type of therapy $(\mathrm{RR}=2.0 ; 0.796-5.027)$, and sex $(\mathrm{RR}=1.917$; 0.928-3.960). Age is a predictor of hypertension $(\mathrm{OR}=1.052 ; \quad \mathrm{CI}=1.034-1.070, \quad \mathrm{P}=0.001), \quad$ and hypertension is significantly correlated with age $(\mathrm{r}=0.416, \mathrm{P}=0.001)$ [25][17].

\section{CONCLUSION}

In conclusion, ARB-CCB is a cost-effective medication to lower blood pressure in hypertensiondiabetes mellitus inpatients, while ACEI-Diuretics offers a cost-effective hypertensive treatment for hypertension-heart failure inpatients.

\section{ACKNOWLEDGMENT}

The authors would like to express their gratitude to Ahmad Dahlan University for funding this research.

\section{REFERENCES}

[1] Sow D, Diédhiou D, Diallo IM, Ndiaye A, Ndour MA, Sarr A, et al. Epidemiological, Clinical and Therapeutic Characteristics of Hypertensive Type 2 Diabetics at the Marc Sankale Center of Dakar. Open J Endocr Metab Dis 2018;08:59-69. https://doi.org/10.4236/ojemd.2018.82007.

[2] Kemenkes RI. Profil Kesehatan Indonesia 2018 [Indonesia Health Profile 2018]. 2019.

[3] Yang Y, Xu H. Comparing six antihypertensive medication classes for preventing new-onset diabetes mellitus among hypertensive patients: a network meta-analysis. J Cell Mol Med 2017;21:1742-50. https://doi.org/10.1111/jcmm.13096.

[4] Baroroh F, Sari A. Analisis Efektivitas Biaya Pengobatan Kombinasi Candesartan-Amlodipin Dibandingkan dengan Kombinasi Candesartan- Diltiazem pada Pasien Hipertensi Rawat Jalan. Pharmacy 2017;14:188-98.

[5] S H, Nissen S. Managing Hypertension in Type 2 Diabetes Mellitus. Best Pract Res Clin Endocrinol Metab 2016; Vol.30 No.3, p.445.

[6] Salagre SB, Itolikar SM, Bhagwat SN. Study of hypertensive subjects with diabetes as co-morbidity. Int J Res Med Sci 2017;5:456. https://doi.org/10.18203/23206012.ijrms20170041.

[7] Ohishi M. Hypertension with diabetes mellitus: Physiology and pathology review-article. Hypertens Res 2018;41:389-93. https://doi.org/10.1038/s41440-018- 
0034-4.

[8] Tatsumi Y, Ohkubo T. Hypertension with diabetes mellitus: Significance from an epidemiological perspective for Japanese. Hypertens Res 2017;40:795-806. https://doi.org/10.1038/hr.2017.67.

[9] Nkoke C, Jingi AM, Aminde LN, Teuwafeu D, Nkouonlack $\mathrm{C}$, Noubiap JJ, et al. Heart failure in a semi-urban setting in Cameroon: clinical characteristics, etiologies, treatment and outcome. J Xiangya Med 2019;4:11-11. https://doi.org/10.21037/jxym.2019.02.01.

[10] Suchard MA, Schuemie MJ, Krumholz HM, You SC, Chen RJ, Pratt N, et al. Comprehensive comparative effectiveness and safety of first- line antihypertensive drug classes: a systematic, multinational, large- scale analysis. Lancet 2019;394:1816-26.

https://doi.org/10.1016/S01406736(19)32317-7.

[11] Di Palo KE, Barone NJ. Hypertension and Heart Failure: Prevention, Targets, and Treatment. Heart Fail Clin 2020;16:99-106. https://doi.org/10.1016/j.hfc.2019.09.001.

[12] Kodera S, Kiyosue A, Ando J, Akazawa H, Morita H, Watanabe M, et al. Cost-effectiveness analysis of cardiovascular disease treatment in Japan. Int Heart $\mathrm{J}$ 2017;58:847-52. https://doi.org/10.1536/ihj.17-365.

[13] He T, Liu X, Li Y, Liu XY, Wu QY, Liu ML, et al. Highdose calcium channel blocker (CCB) monotherapy vs combination therapy of standard- dose $\mathrm{CCBs}$ and angiotensin receptor blockers for hypertension: A metaanalysis. J Hum Hypertens 2017;31:79-88. https://doi.org/10.1038/jhh.2016.46.

[14] Venkataraman R, Mathai JM, Thomas L, James M. Impact of demographic variables on blood pressure and glycemic control. Asian J Pharm Clin Res

2018;11:179-81.

https://doi.org/10.22159/ajpcr.2018.v11i10.25599.

[15] Momoniat T, Ilyas D, Bhandari S. ACE inhibitors and ARBs: Managing potassium and renal function. Cleve Clin J Med 2019;86:601-7. https://doi.org/10.3949/ccjm.86a.18024.

[16] Li WW, Vittinghoff E, Fukuoka Y. Predictors for Blood Pressure Reduction in American Latinos: Secondary Analysis of the Adelgaza Program Data. Hisp Heal Care Int 2020;18:77-84. https://doi.org/10.1177/1540415319869936.

[17] Tsai MS, Tang CH, Lin CY, Chuang PY, Chen NC, Huang $\mathrm{CH}$, et al. Diuretic or Beta-Blocker for Hypertensive Patients Already Receiving ACEI/ARB and Calcium Channel Blocker. Cardiovasc Drugs Ther 2017;31:535-43. https://doi.org/10.1007/s10557-017-6765-7.

[18] Hasan D. Cost-Effectiveness Analysis of Antihypertensive Drugs Usage by Combination of ACEI - CCB and ACEI Diuretic in Outpatient Hypertension Therapy at RSAL Mintohardjo Jakarta. Value Heal 2015; Vol.19 No.

[19] Antonella AM, Paola Sacco, Danyelle M.Townsend, Contatto E, Cappello I, Schiavon L, Ramazzina E, Rubello D C. Effectiveness of Angiotensin- II Receptor Blockers in Patients with Uncomplicated Hypertension: A Comparative Analysis, Biomedicine \& Pharmacotherapy 2017; Vol.90 pp.

[20] Omboni S, Volpe M. Angiotensin Receptor Blockers Versus Angiotensin Converting Enzyme Inhibitors for the
Treatment of Arterial Hypertension and the Role of Olmesartan. Adv Ther 2019;36:278-97. https://doi.org/10.1007/s12325-018-0859-x.

[21] Wu Y, Zhou Q, Xuan J, Li M, Zelt S, Huang Y, et al. A cost- effectiveness analysis between amlodipine and angiotensin ii receptor blockers in stroke and myocardial infarction prevention among hypertension patients in China. Value Heal Reg Issues 2013;2:75-80. https://doi.org/10.1016/j.vhri.2013.01.005.

[22] Park C, Wang G, Durthaler JM, Fang J. Cost-effectiveness Analyses of Antihypertensive Medicines: A Systematic Review. Am J Prev Med 2017;53:S131-42. https://doi.org/10.1016/j.amepre.2017.06.020.

[23] Gaziano TA, Fonarow GC, Claggett B, Chan WW, Deschaseaux- Voinet C, Turner SJ, et al. Cost-effectiveness analysis of sacubitril/valsartan vs enalapril in patients with heart failure and reduced ejection fraction. JAMA Cardiol 2016;1:666-72.

https://doi.org/10.1001/jamacardio.2016.1747.

[24] Amir, Weber, Beard, Bomyea T. 基因的改变NIH Public Access. Bone 2008;23:1-7. https://doi.org/10.1161/CIRCULATIONAHA.110.983874. Meta- Analysis.

[25] Olanrewaju TO, Aderibigbe A, Popoola AA, Braimoh KT, Buhari MO, Adedoyin OT, et al. Prevalence of chronic kidney disease and risk factors in North-Central Nigeria: a population-based survey. BMC Nephrol 2020;21:1-10. https://doi.org/10.1186/s12882-020- 02126 